\title{
The pregnancy as protection for suicidal behavior: a population-based study in south Brazil
}

\author{
A gestação como proteção para o comportamento suicida: um estudo de base \\ populacional no sul do Brasil
}
El embarazo como la protección del comportamiento del suicidio: un estudio basado en la población en el sur de Brasil

Jéssica Puchalski Trettim¹, Mariana Bonati de Matos ${ }^{1}$, Gabriela Kurz da Cunha ${ }^{1}$, Clarissa Ribeiro de Souza Martins ${ }^{1}$, Bárbara Borges Rubin ${ }^{1}$, Carolina Coelho Scholl ${ }^{1}$, Daniele Behling de Mello ${ }^{1}$, Ana Paula Ardais ${ }^{1}$, Janaína Vieira dos Santos Motta ${ }^{1}$, Fernanda Nedel ${ }^{1}$, Gabriele Cordenonzi Ghisleni ${ }^{1}$, Karen Amaral Tavares Pinheiro², Ricardo Tavares Pinheiro ${ }^{1 *}$, Luciana de Avila Quevedo1.

\begin{abstract}
Objective: To describe the incidence of suicidal attempts and the prevalence of suicidal ideation in pregnancy; verifying the factors associated with suicidal ideation in pregnant women. Methods: This analysis is a section from a population-based cohort study with pregnant women between the first and second gestational trimester, identified at their homes in the urban area from a southern Brazilian. The Mini International Neuropsychiatric Interview version Plus (MINI PLUS) was used to assess suicidal ideation and behavior. Variables with a $p<0.20$ value in the bivariate analysis were retained in the logistic regression-adjusted analysis using SPSS (Statistical Package for the Social Sciences) Statistics software. This study was approved by the Research Ethics Committee of the Catholic University of Pelotas. Results: In the baseline, 974 pregnancy women completed the diagnostic interview for evaluation of psychiatric symptoms, totaling $9.5 \%(n=93)$ woman had current suicidal ideation. In addition, $1.3 \%(n=13)$ of pregnant women reported a suicide attempt in the last month, and 11 of them had a history of suicidal behavior throughout their lives. Conclusion: Despite the presence of suicidal ideas in pregnancy, suicidal behavior is not very common at this time.
\end{abstract}

Keywords: Suicidal ideation, Self-Injurious behavior, Pregnancy.

\section{RESUMO}

Objetivo: Descrever as taxas de incidência de tentativa de suicídio e prevalência de ideação suicida na gestação, verificando os fatores associados à ideação suicida em gestantes. Métodos: Esta análise é um recorte de uma coorte de base populacional com gestantes entre o primeiro e o segundo trimestre gestacional, identificadas em seus domicílios na zona urbana de uma cidade do sul do Brasil. A Mini International Neuropsychiatric Interview versão Plus (MINI PLUS) foi utilizada para avaliar a ideação e o comportamento suicida. Variáveis com $p$-valor $<0.20$ na análise bivariada foram levadas para análise ajustada por regressão logística utilizando o SPSS (Statistical Package for the Social Sciences) Statistics software. Este estudo foi aprovado pelo Comitê de Ética em Pesquisa. Resultados: No baseline, 974 gestantes completaram a entrevista diagnóstica para avaliação dos sintomas psiquiátricos, totalizando $9.5 \%(n=93)$ mulheres com

\footnotetext{
1 Postgraduate Program in Health and Behavior, Catholic University of Pelotas. Pelotas, RS, Brazil.

*E-mail: ricardop@terra.com.br

${ }^{2}$ Federal University of Rio Grande. Rio Grande, RS, Brazil.
}

This work was supported by CNPq/Brazil, Bill \& Melinda Gates Foundation (Process 401726/2015-0 APP/Call 47/2014). 
ideação suicida atual. Além disso, 1.3\% $(n=13)$ das gestantes relataram tentativa de suicídio no último mês, e destas 11 tinham histórico de comportamento suicida ao longo da vida. Conclusão: Apesar da presença de ideias suicidas durante a gestação, o comportamento suicida é pouco incidente neste momento.

Palavras-chave: Ideação suicida, Comportamento autodestrutivo, Gestação.

\section{RESUMEN}

Objetivo: Describir las tasas de la incidencia los intentos del suicidio y la prevalencia la ideación suicida en el embarazo, verificando los factores asociados con la ideación suicida en las mujeres embarazadas. Métodos: Este análisis es una sección de una cohorte poblacional con mujeres embarazadas entre el primer y el segundo trimestre de gestación, identificado en sus hogares en el área urbana de una ciudad del sur de Brasil. Se utilizó la versión Mini International Neuropsychiatric Interview Plus (MINI PLUS) para evaluar la ideación y el comportamiento suicidas. Las variables con valor del $p<0,20$ en el análisis bivariado se tomaron para el análisis ajustado por la regresión logística utilizando el software SPSS (Statistical Package for the Social Sciences) Statistics. Este estudio fue aprobado por el Comité de Ética en Investigación. Resultados: Al inicio del estudio, 974 mujeres embarazadas completaron la entrevista del diagnóstico para evaluar los síntomas psiquiátricos, totalizando el 9,5\% $(n=93)$ mujeres con ideación suicida actual. Además, el 1.3\% $(n=13)$ de las mujeres embarazadas reportaron intentos del suicidio en el último mes, y de estos 11 tenían antecedentes de comportamiento suicida a lo largo de sus vidas. Conclusión: A pesar de la presencia de las ideas suicidas en el embarazo, el comportamiento suicida no es muy común en este momento.

Palabra clave: Ideación suicida, Comportamiento autodestructivo, Embarazo.

\section{INTRODUCTION}

According to the World Health Organization (WHO), suicide is among the three leading causes of death among adults, accounting for $1.4 \%$ of all deaths worldwide, with rates 10 to 20 times higher when considering the attempts (BOTEGA NJ, 2014). Brazil is among the ten countries with the highest number of suicides in the world, being recognized as a global public health problem (WORLD HEALTH ORGANIZATION, 2014). The term suicidality covers suicidal ideation (serious thoughts about taking one's own life), suicide plans and suicide attempts, involving self-injury with the intent to end one's life (NOCK MK, et al., 2008; LUO M, et al., 2018).

Regarding the gender differences, 2012 data showed that 10.7 men and 3.4 women by 100.000 people took their own lives (MOURA ECD, et al., 2015). In Brazil, suicidal behavior rates are three times higher among men in all regions, but the highest growth has been recorded among women, with the highest mortality in the southern region. Therefore, males have a higher prevalence of suicide, while females have a higher rate of attempts, with death being the most frequent outcome among men than women (VIEIRA RG, et al., 2017).

Some periods of the life cycle may leave the individual more vulnerable to suicide risk. Pregnancy, for example, is an event that involves numerous physiological and psychological changes and understanding and distinguishing these characteristics is important, especially among pregnant women. The hormonal changes induce rapid increased levels of estrogen and progesterone, which have been linked to symptoms of depression in pregnancy and postpartum (HENDRICK V, et al., 1998; SCHILLER CE, et al. 2014). Therefore, this period is directly associated with the onset or exacerbation of some psychological symptoms, such as suicidal ideation.

Studies examining maternal mental health have been the focus of greater attention and highlight that pregnant women are at increased risk of suicidal thoughts and behaviors compared to the general population (GENTILE S, et al. 2011; ONAH MN, et al., 2017). During pregnancy, suicidal behavior has been reported at rates ranging from $2.7 \%$ to $14.0 \%$ (PINHEIRO RT, et al., 2008; GAUSIA K, et al., 2009; GAVIN AR, et al., 2011) and a higher prevalence $(33.0 \%)$ in a sample of women with a history of neuropsychiatric disease (NEWPORT DJ, et al., 2007). 
With regards to suicidal ideation, studies suggest that in some cases, suicidal ideation is considered a predictor of further suicide attempt (GELAYE B, et al., 2016). Although suicidal ideation is an important factor of suffering, few studies address this issue, especially in pregnant women, where $35 \%$ of suicide ideation was found to be prevalent (NEWPORT DJ, et al., 2007). Conversely, some studies have showed that suicide risk occur at a lower rate during the pregnancy and the postpartum period than in the general population. This finding reinforces the need for further investigation regarding this particular problem (BOUCHIATCOUCHOURON S, et al., 2009; WALLACE ME, et al., 2016).

In addition, it is also important to identify the risk factors that are more relevant to this population, since there is no consensus in the literature on the factors associated with suicidality. Benute GEG, et al. (2011) found no sociodemographic data related to these symptoms, while others studies describe that suicidality during pregnancy may be associated with some factors like not being married, low socio-economic status and low levels of education, (BENUTE GRG, et al., 2011; GELAYE B, et al., 2016), sleep quality (GELAYE B, et al., 2015), substance abuse/dependence (GUILLARD $V$ and GRESSIER F, 2017) and history of neuropsychiatric disease (NEWPORT DJ, et al., 2007). Moreover, in the study by Onah MN, et al. (2017), aspects such as food insecurity, interpersonal violence, multiparity and previous suicide attempt were associated with suicide risk during pregnancy (ONAH MN, et al., 2017).

Current research seeks to clarify whether pregnancy is a period characterized by a greater presence of ideas and suicide attempts (because of the changes mentioned previously) when compared to other moments of the life cycle (ONAH MN, et al., 2017). Maternal mental health can affect the quality of the mother-child interaction and, consequently, the development of the child (SCHWANZ CC, 2010). Therefore, a specialized investigation for the identification and treatment of psychiatric conditions in the perinatal period should be a priority in the maternity care service.

This study aimed to describe the incidence of suicidal attempts and the prevalence of suicidal ideation in pregnancy, verifying the factors associated with suicidal ideation in pregnant women up to their second trimester of gestation.

\section{METHODS}

This analysis is a section from a population-based cohort study with pregnant living in the urban area of a city in the south of Brazil. Sample was carried out in multiple stages, according to the 2010 of Brazilian Institute of Statistic (IBGE) census of 244 sectors of the city $(50.0 \%$ of the total). The census sectors were randomly selected. Next, between May 2016 and August 2018, we approached women who were up to 24 weeks of pregnancy to participate in the study. These pregnant women signed the free and informed consent form and answered a questionnaire during a household interview to provide socio-demographic, behavioral and mental health information to be considered in our analysis.

The Mini International Neuropsychiatric Interview version Plus (MINI PLUS) was used to assess major depressive episode current and to evaluate suicidal ideation and behavior. To create the variable suicidal ideation (no/yes), at least one positive answer to the following questions was considered: "Did you think that you would be better off dead or wish you were dead?" or "Did you want to harm yourself?" or "Did you think about suicide?" or "Did you plan for a suicide?". The same criteria were used to assess life-long suicidal behavior with the following questions: "Over the past month, did you attempt suicide?" or "Have you ever attempted suicide in your life?" (AMORIM P, 2000).

The Beck Anxiety Inventory (BAl) was used to evaluate the presence of anxiety symptoms. The scale contains 21 descriptive items of the most common anxiety symptoms on a 4-point likert scale. The total score ranges from 0 to 63 points, with higher scores indicating greater severity of the anxiety symptoms. For this study, the cutoff 11 was used for the presence of anxiety symptoms (BECK AT, et al., 1988; CUNHA JA, 2001).

The Biological Rhythm Interview of Assessment in Neuropsychiatry (BRIAN) allows an evaluation of the biological rhythm, with indexes clinically interpretable by researchers. The 18 total items of the scale are divided into four specific areas: sleep, activities, social rhythm and food pattern, evaluated over the last 15 
days. For the present study, only the sleep domain, which contains 5 items, was included in the analyzes. Scores range from 1 (no difficulty) to 4 (very difficult) to evaluate the maintenance of normal rhythm (GIGLIO LM, et al., 2009). It should be noted that sleep is a commonly altered factor in the gestational period and therefore we defined cutoff 13 points to allow the comparison of these scores in our sample.

The specifics modules of alcohol and tobacco of Alcohol Smoking and Substance Involvement Screening Test (ASSIST), was selected for this study (HENRIQUE IFS, et al. 2004). Each answer corresponds to a score ranging from 0 to 4 , with the total score ranging from 0 to 20 . The score range 0 to 3 indicated occasional use of alcohol and tobacco, 4 to 15 revealed abuse and $\geq 16$ as suggestive of addiction. For this study the classification of abuse/dependence was considered.

The socio-economic status was assessed through Brazilian Association of Research Companies (ABEP), which is based on the accumulation of material assets and the education of the head of the family, among other criteria. Participants are divided into groups (A, B, C, D or E) from the scores achieved, with the letter "A" referring to the highest socioeconomic class and the lowest "E". For this study, the levels were grouped as follows: High $(A+B)$, middle $(C)$ and lower levels $(D+E)(A B E P, 2015)$.

The statistical analysis was performed using the statistical software Statistical Package for Social Sciences (SPSS), version 21.0 through a univariate analysis to describe the characteristics of the sample and the prevalence of suicidal ideation and incidence of suicidal attempts. Values that present a p-value $<0.20$ in the bivariate analysis (age, economic class, live with a partner, major depressive episode current, anxious symptoms, sleep deregulation, abuse/dependence tobacco and alcohol and history of suicidal behavior) were retained in the analysis adjusted by logistic regression. P-values $<0.05$ were considered to indicate statistical significance.

All subjects gave written informed consent for the analysis and anonymous publication of research findings. In the cases of underage pregnant women, the term was signed by a responsible person. All women who reported thoughts or attempted suicide (current or past) were referred to the public health service. This research was approved by the Research Ethics Committee of the Catholic University of Pelotas under the protocol 47807915.4.0000.5339.

\section{RESULTS}

A total of 981 pregnant women were identified in the present study. Of these, 974 completed the diagnostic interview for evaluation of mental health. The prevalence of current suicidal ideation was $9.5 \%(\mathrm{~N}=93)$.

Table 1 shows sample's distribution, bivariate and multivariate analysis. In the adjusted analysis, it was found that older pregnant women had $3.1(95 \% \mathrm{Cl}$ [confidence interval] $1.4 ; 6.5)$ more ideas when compared to younger women, as well as those in middle class (C) had 2.3 times more suicide ideas in relation to those in higher classes (A or B) $(95 \% \mathrm{Cl} 1.0 ; 5.2)$.

Also, those who didn't live with their partners were $2.7(95 \% \mathrm{Cl} 1.5 ; 5.0)$ times more likely to have suicidal ideation compared to those who lived with their partners. Pregnant women diagnosed with a current major depressive episode exhibited 10.3 times more ideation when compared to those without this diagnosis $(95 \%$ $\mathrm{Cl} 5.6 ; 8.9)$; women with anxious symptoms were $8.8(95 \% \mathrm{Cl} 4.3 ; 18.1)$ times more likely to have ideation compared to those without anxious symptoms. We also found that pregnant women with sleep alterations had a 1.9 higher probability $(95 \% \mathrm{Cl} 1.0 ; 3.4)$ of presenting suicidal ideation. Regarding a past history of suicidal behavior, these women were 4.3 times more likely to exhibit current suicidal ideation $(95 \% \mathrm{Cl} 2.2 ; 8.2)$. The variables tobacco and alcohol abuse/dependence were not associated with suicidal ideation $(p>0.05)$. (Table 1)

Our main result was that among the 93 pregnant women who presented suicidal ideation, 13 reported suicide attempt in the last month and of these, 11 had a history of suicidal behavior throughout life (PR 4.3; $95 \% \mathrm{Cl} 2.2 ; 8.2)$. Thus, we can consider that the incidence of suicidal behavior in our sample of pregnant women was minimal, with only two cases $(2.2 \%$ of total sample) (Figure 1). 
Table 1 - Sample characteristics, bivariate and adjusted analysis of pregnant women with suicidal ideation.

\begin{tabular}{|c|c|c|c|c|c|}
\hline \multirow{2}{*}{ Variables } & \multicolumn{5}{|c|}{ Suicidal ideation* } \\
\hline & N (\%) & $\mathbf{N}(\%)$ & p-value & PR (Cl 95\%) & p-value \\
\hline Age & \multicolumn{5}{|c|}{0.088} \\
\hline up to 34 years & $853(87.0)$ & $75(8.9)$ & & 1 & \\
\hline 35 years or more & $128(13.0)$ & $18(14.1)$ & & $3.1(1.4 ; 6.5)$ & 0.003 \\
\hline Economic class ${ }^{\star}$ & \multicolumn{5}{|c|}{0.062} \\
\hline High classes & $247(25.8)$ & $14(5.7)$ & & 1 & \\
\hline Middle class & $547(57.2)$ & $56(10.3)$ & & $2.3(1.0 ; 5.2)$ & 0.046 \\
\hline Lower classes & $162(16.9)$ & $19(11.8)$ & & $1.7(0.6 ; 4.6)$ & 0.312 \\
\hline Live with partner* & \multicolumn{5}{|c|}{$<0.001$} \\
\hline Yes & $792(80.8)$ & $55(7.0)$ & & 1 & \\
\hline No & $188(19.2)$ & $38(20.5)$ & & $2.7(1.5 ; 5.0)$ & 0.002 \\
\hline Education & \multicolumn{5}{|c|}{0.398} \\
\hline Up to 8 years & $324(33.0)$ & $31(9.7)$ & & - & - \\
\hline 9 to 11 & $360(36.7)$ & $39(10.9)$ & & - & - \\
\hline 12 or more & $297(30.3)$ & $23(7.8)$ & & - & - \\
\hline Major depressive episode current ${ }^{\star}$ & \multicolumn{5}{|c|}{$<0.001$} \\
\hline No & $866(88.9)$ & $39(4.5)$ & & 1 & \\
\hline Yes & $108(11.1)$ & $54(50.0)$ & & $10.3(5.6 ; 18.9)$ & $<0.001$ \\
\hline Anxious symptoms ${ }^{*}$ & \multicolumn{5}{|c|}{$<0.001$} \\
\hline No & $663(67.7)$ & $14(2.1)$ & & 1 & \\
\hline Yes & $317(32.3)$ & $79(25.0)$ & & $8.8(4.3 ; 18.1)$ & $<0.001$ \\
\hline Sleep deregulation & \multicolumn{5}{|c|}{$<0.001$} \\
\hline Up to 12 points & $775(79.0)$ & $41(5.3)$ & & 1 & \\
\hline 13 to 20 points & $206(21.0)$ & $52(25.4)$ & & $1.9(1.0 ; 3.4)$ & 0.036 \\
\hline Abuse/dependence tobacco* & \multicolumn{5}{|c|}{0.005} \\
\hline No & $820(83.8)$ & $68(8.3)$ & & 1 & \\
\hline Yes & $158(16.2)$ & $25(15.8)$ & & $1.8(0.9 ; 3.6)$ & 0.099 \\
\hline Abuse/dependence of alcohol* & \multicolumn{5}{|c|}{0.177} \\
\hline No & $894(91.4)$ & $81(9.1)$ & & 1 & \\
\hline Yes & $84(8.6)$ & $12(14.3)$ & & $0.8(0.3 ; 2.0)$ & 0.629 \\
\hline History of suicidal behavior* & \multicolumn{5}{|c|}{$<0.001$} \\
\hline No & $865(88.8)$ & $57(6.6)$ & & 1 & \\
\hline Yes & $109(11.2)$ & $36(33.0)$ & & $4.3(2.2 ; 8.2)$ & $<0.001$ \\
\hline Total & $981(100.0)$ & $93(9.5)$ & - & - & - \\
\hline
\end{tabular}


Figure 1 - Prevalence and incidence of suicidal behavior in pregnant women with suicidal ideation.

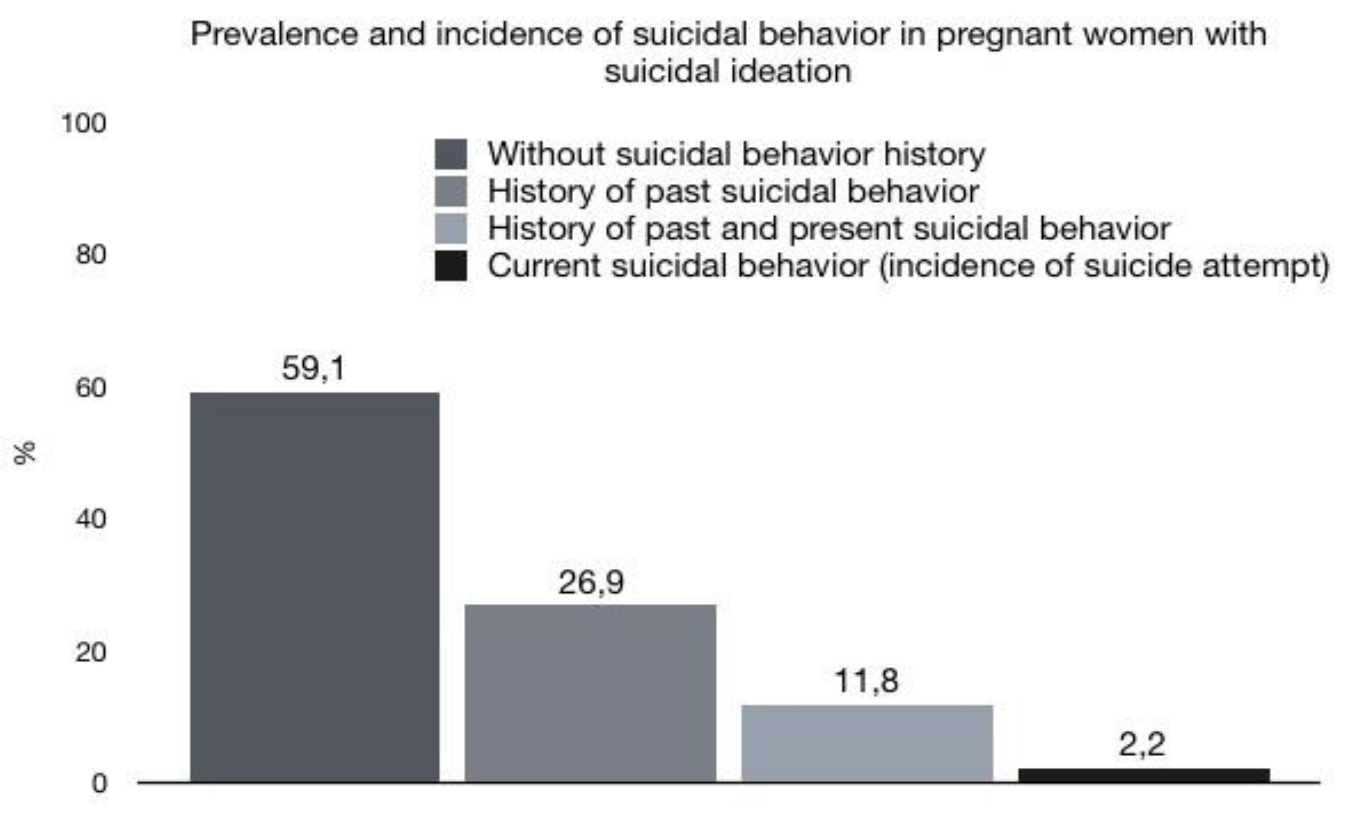

Source: Trettim JP, et al., 2019.

\section{DISCUSSION}

This study described the incidence of suicidal attempts and the prevalence of suicidal ideation in pregnant women, verifying the factors associated with suicidal ideation. This prevalence was higher among older pregnant women, from the middle class, who didn't live with a partner, with anxious symptoms, sleep deregulation, and with history of suicide attempt. This finding regarding the prevalence of suicidal ideation is consistent with that obtained in recent studies that have showed a prevalence ranging from $6.3 \%$ to $14.0 \%$ for low and middle income countries (ONAH MN, et al., 2017).

Although pregnant women with a history of attempted suicide had $33 \%$ current ideas, the incidence of suicidal behavior (current suicide attempt) in our sample of pregnant women was minimal (only two cases), indicating that pregnancy seems to act as a protective event for suicide behavior. Some previous studies on the role of the reproductive cycle in women have also indicated that motherhood (including pregnancy and postpartum) plays an important role in reducing suicide rates, as this is a period where the mother-to-be is responsible not only for her own life but also for the life of her newborn (NEWPORT DJ, et al., 2007; ORSOLINI L, et al., 2016; WALLACE ME, et al., 2016). This data is also controversial, since studies have showed that the gestational period is a risk factor for suicidal behavior (MCLEAN J, et al., 2008). This aspect needs further investigation, and the main question remains: "Do pregnant women have a lower rate of suicide attempts when compared to the young women in the general population?"

Our finding regarding age goes against most literature data, which indicate that younger pregnant women are more likely to show suicidal ideas in the gestational period. Many studies have reported that younger pregnant women have more suicidal ideation than older women (GANDHI SG, et al., 2006; KIM JJ, et al. 2015, GELAYE B, et al. 2016), but other studies have not found this association (NEWPORT DJ, et al., 2007; BENUTE GRG, et al., 2011).

Wallace ME, et al. (2016) reported that older women were at greater risk for suicide during pregnancy. However, these authors did not discuss this finding but only referred to it as a suicide trend in the general population (WALLACE ME, et al., 2016). Therefore, this contraction deserves some further investigated, as there is no consensus in the literature regarding age as a risk factor for the presence of suicidal thoughts in pregnancy. 
The analysis of the economic factors revealed that middle-class pregnant women had more suicidal ideation when compared to higher-income pregnant women. However, those women from lower classes did not maintain this association in the multivariate analysis. Some studies also found that lower economic classes are related to a higher chance of suicide during pregnancy, because of greater exposure to vulnerability, concerns and hopelessness (GELAYE B, et al., 2016; ONAH MN, et al., 2017). This result emphasizes the need for greater attention to social policies to target economically disadvantaged pregnant women.

We also found that women who did not live with their partners showed more thoughts of suicide compared to those who were living with a partner. It is understood that not living with the partner can result in a lower perception of social and emotional support. Also, this situation can directly interfere in women's mental health during pregnancy (ONAH MN, et al., 2017).

Moreover, the literature indicates that comorbidity in psychiatric disorders, mainly depression and anxiety, are the most worrying risk factors for ideation and suicidal behavior during the pregnancy (TABB KM, et al., 2013; ONAH MN, et al., 2017).

Despite this, we strongly suggest an investigation for an effective diagnosis independently of the presence of other disorders, to avoid that pregnant women without these disorders, who are at risk of suicide, are neglected. Grigoriadis S, et al. (2017) reported that the most of the women who died in perinatal had a mood or anxiety disorder (GRIGORIADIS S, et al., 2017). Thus, pregnancy and postpartum are periods when a woman is most vulnerable to the negative consequences or exacerbation of psychiatric symptoms due to of the hormonal and social changes experienced at that time.

Our findings also revealed that pregnant women with more sleep deregulation had almost twice as much suicidal ideation as those with less sleep problems. However, it is worth mentioning that sleep is one of the commonly altered aspects during pregnancy. Researchers also found a relationship between sleep quality and suicidal ideation in pregnant women; those who did not sleep well were significantly more likely to present suicidal thoughts (GELAYE B, et al., 2015).

We should be aware of potential limitations, particularly information bias. Pregnant women experience intense family and social pressure when it comes to suicidal ideation, even more so when suicidal behavior is questioned. Talking about suicidal behavior can become a reason for a defensive response. However, considering that a large number of individuals claimed to have suicidal ideation and planning, this indicates less defensiveness. In addition, the applied instrument is a gold standard for such situations, minimizing possible information bias.

It is noteworthy that the presence of suicidal thoughts is involuntary and causes much suffering, especially in pregnant women. Our findings may assist in the understanding of suicidal ideation during pregnancy. It should be emphasized that these results confirmed the high rate of suicidal ideation during pregnancy; however, suicidal attempts is not an incident. The result obtained regarding ideation has focused attention on the importance of mental health in pregnant women. However, suicidal behavior may be less frequent during pregnancy due to the fact that women are responsible not only for their own lives, but also for the life of the baby. Despite the low incidence of suicidal behavior in our sample of pregnant women, this does not diminish the suffering caused by symptoms at the level of suicidal thoughts. Consequently, these thoughts need to be identified and treated at this stage, thus avoiding a possible aggravation.

Prepartum suicidal ideation is a relatively common complication and requires greater attention given its association with many adverse maternal, fetal, of bond and infant outcomes. Mother-infant bonding and child development may be affected by these thoughts. Prevention strategies such as those advocated by the WHO should consider pregnant women as a target study population (WORLD HEALTH ORGANIZATION, 2006).

\section{CONCLUSIONS}

Finally, we believe that services for pregnant women should focus on women with history of attempts, because they may be at risk. Also we suggest that further investigation examining other factors that contribute 
to the presence of suicidal ideas in pregnancy should be carefully considered. Some prevention strategies should include the use of psychometric scales and diagnostic interviews to facilitate the identification and consequent management of this problem in prenatal care services.

\section{FUNDIND and ACKNOWLEDGEMENT}

This work was supported by CNPq/Brazil, Bill \& Melinda Gates Foundation (Process 401726/2015-0 APP/Call 47/2014) and Ministry of Health/INCT-DCEN (National Institute of Science and Technology). We would like to thank the Bill \& Melinda Gates Foundation, also the Coordenação de Aperfeiçoamento de Pessoal de Nível Superior (Capes) and Conselho Nacional de Desenvolvimento Científico e Tecnológico (CNPq). Special thanks to the pregnant women who participated in our study.

\section{REFERENCES}

1. ABEP. Dados com base no Levantamento Sócio Econômico 2014 2015. Acessed november $01,2017$.

2. AMORIM P. Mini International Neuropsychiatric Interview (MINI): validação de entrevista breve para diagnóstico de transtornos mentais. Revista Brasileira de Psiquiatria. 2000; 22(3):106-115.

3. BECK AT, et al. An inventory for measuring clinical anxiety: psychometric properties. Journal of Consulting and Clinical Psychology, 1988; 56(6):893-7.

4. BENUTE GRG, et al. Risco de suicídio em gestantes de alto risco: um estudo exploratório. Revista da Associação Médica Brasileira, 2011; 57(5):583-587.

5. BOTEGA NJ. Comportamento suicida: epidemiologia. Psicologia Universidade de São Paulo. 2014; 25(3):231-236.

6. BOUCHIAT-COUCHOURON S, et al. Suicidal crises at the time of motherhood. La Revue du praticien, 2009; 59(8):1051-7.

7. CUNHA JA. Manual da versão em português das escalas Beck. São Paulo: Casa do Psicólogo; 2001.

8. CHUA EW, et al. Metoclopramide-Induced Acute Dystonic Reactions May Be Associated With the CYP2D6 Poor Metabolizer Status and Pregnancy-Related Hormonal Changes. Frontiers in Pharmacology. 2019; 10:931.

9. GANDHI SG, et al. Maternal and neonatal outcomes after attempted suicide. Obstetrics and Gynecology, 2006; 107(5):984-90.

10. GAUSIA K, et al. Antenatal depression and suicidal ideation among rural Bangladeshi women: a community-based study. Archives of Womens Mental Health, 2009; 12(5):351-8.

11. GAVIN AR, et al. Prevalence and correlates of suicidal ideation during pregnancy. Archives of Womens Ment Health, $2011 ; 14(3): 239-46$.

12. GELAYE B, et al. Association of poor subjective sleep quality with suicidal ideation among pregnant Peruvian women. General Hospital Psychiatry, 2015; 37(5):441-7.

13. GELAYE B, et al. Suicidal ideation in pregnancy: an epidemiologic review. Archives of Women's Mental Health, 2016; 19(5):741-51.

14. GENTILE S. Suicidal mothers. Journal of Injury and Violence Research, 2011 3(2):90-7.

15. GIGLIO LM, et al. Development and use of a biological rhythm interview. Journal of Affective Disorders, 2009; 118(13):161-5.

16. GRIGORIADIS S, et al. Perinatal suicide in Ontario, Canada: a 15-year population-based study. Canadian Medical Association Journal, 2017; 189(34):1085-1092.

17. GUILLARD V, GRESSIER F. Suicidality during perinatal period. Presse Medicale, 2017; 565-571.

18. HENDRICK V, et al. Hormonal Changes in the Postpartum and Implications for Postpartum Depression. Psychosomatics, 1998; 39(2):93-101.

19. HENRIQUE IFS, et al. Validação da versão brasileira do teste de triagem do envolvimento com álcool, cigarro e outras substâncias (ASSIST). Revista da Associação Médica Brasileira, 2004; 50(2):199-206.

20. KIM JJ, et al. Suicide risk among perinatal women who report thoughts of self-harm on depression screens. Obstetrics and Gynecology, 2015; 125(4):885-93.

21. LUO M, et al. Association between induced abortion and suicidal ideation among unmarried female migrant workers in three metropolitan cities in China: a cross-sectional study. BMC Public Health, 2018; 18:625.

22. MOURA ECD, et al. Gender inequalities in external cause mortality in Brazil, 2010. Ciência \& Saúde Coletiva, 2015; 20(3):779-788.

23. MCLEAN J, et al. Risk and Protective Factors for Suicide and Suicidal Behaviour. Scottish Government; $2008 ; 145$ p. 
24. NEWPORT DJ, et al. Suicidal ideation in pregnancy: assessment and clinical implications. Archives of Women's Mental Health, 2007; 10(5):181-7.

25. NOCK MK, et al. Suicide and Suicidal Behavior. Epidemiologic Reviews. 2008; 30:133-54.

26. ONAH MN, et al. Perinatal suicidal ideation and behaviour: psychiatry and adversity. Archives of Women's Mental Health, 2017; 20(2):321-331.

27. ORSOLINI L, et al. Suicide during Perinatal Period: Epidemiology, Risk Factors, and Clinical Correlates. Frontiers in psychiatry, 2016; 7:138-138.

28. PINHEIRO RT, et al. Suicidal behavior in pregnant teenagers in southern Brazil: social, obstetric and psychiatric correlates. Journal of Affective Disorders, 2012; 136(3):520-5.

29. SCHILLER CE, et al. The role of reproductive hormones in postpartum depression. CNS Spectrums, 2014; 20(01):4859.

30. SCHWANZ, C. Depressão pós-parto materna e desenvolvimento motor de bebês no quarto mês de vida. Dissertação (Mestrado em Saúde e Comportamento) - Universidade Católica de Pelotas, Pelotas, 2013, 65 p.

31. TABB KM, et al. Views and experiences of suicidal ideation during pregnancy and the postpartum: findings from interviews with maternal care clinic patients. Women Health, 2013; 53(5); 519-35.

32. VIEIRA RG, et al. Prevalência e risco de suicídio no Brasil e na cidade de Barra do Garças (MT): Revisão de literatura. Revista Debates em Psiquiatria, 2017 p. 10-14.

33. WALLACE ME, et al. Pregnancy-associated homicide and suicide in 37 US states with enhanced pregnancy surveillance. American Journal of Obstetrics and Gynecology, 2016; 215(3):364.e1-364.e10.

34. WORLD HEALTH ORGANIZATION, 2014. Country reports and charts available. Accessed October 10, 2019.

35. ZHONG QY, et al. Childhood abuse and suicidal ideation in a cohort of pregnant Peruvian women. American Journal of Obstetrics \& Gynecology 2016; 215(4):501. 